\title{
EFFECT OF NITROGEN FERTILIZATION AND DIAZOTROPH INOCULATION ON YIELD OF SOLID AND INTERCROPPED MAIZE WITH SOYBEAN
}

\author{
Metwally, A. A. ${ }^{1}$; M. M. Shafik ${ }^{1}$; M. Fayez ${ }^{2}$ and S. A. Safina ${ }^{1}$ \\ 1 Department of Agronomy, Fac. of Agriculture, Cairo University, Giza, \\ Egypt. \\ 2 Department of Microbiology, Fac. of Agriculture, Cairo University, \\ Giza, Egypt.
}

\begin{abstract}
Two field trials were conducted at the Agricultural Experiment and Research Station, Faculty of Agriculture, Cairo University, Giza, at 2004 and 2005 summer seasons. The objectives of this study were to investigate the effect of diazotroph inoculation and nitrogen levels $(60,90$ and $120 \mathrm{~kg} \mathrm{~N} /$ faddan) on yield and yield components of solid and intercropped maize. Maize variety (Single hybrid 122) and soybean variety (Giza 111) were used in this study. Leaf Area Index (LAI) was significantly higher under intercropping than solid1 (recommended planting). Doupling the plant population density in solid2 reduced significantly biological and grain yield/plant, than those obtained by intercropping and recommended solid planting (solid1). In general, grain yield/faddan was significantly higher under the solid1 (23.58 ardab/fad.) than under solid2 (23.14 ardab/fad.) and intercropping (19.81 ardab/fad.) plantings. Increasing nitrogen application rates till $120 \mathrm{~kg} \mathrm{~N} /$ fad increased LAI, biological yield, grain yield/plant and grain yield/fad. The biological yield/plant, grain yield/plant and grain yield/ faddan due to inoculation were 13.5, 12.7 and $7.8 \%$, respectively higher compared to uninoculated maize. Inoculation seeds and fertilization of maize with $90 \mathrm{~kg} \mathrm{~N} /$ faddan possessed higher values of biological, grain yield/plant and per faddan under recommended solid and intercropping patterns, with no significant differences as compared with $120 \mathrm{~kg} \mathrm{~N} /$ faddan. The effect of inoculation under zero $\mathrm{N}$ level was higher than those of high doses of nitrogen levels under recommended solid and interplanting cultures. Appling 60 and $90 \mathrm{~kg} \mathrm{~N} / \mathrm{faddan}$ in presence of diazotroph inoculation resulted in same yields as 90 - and $120 \mathrm{~kg}$ $\mathrm{N} /$ faddan in absence of inoculation. This means that the microbial formulation "Biogramina" of associative diazotrophs successfully replaced $30 \mathrm{~kg} \mathrm{~N} / \mathrm{fad}$ for maize plants.
\end{abstract}

\section{INTRODUCTION}

Maize (Zea mays L.) is the first summer cereal crop in Egypt considering acreage, and total production. It occupies one third of the cultivated acreage of 2.25 million faddans. Soybean (Glycine max L. Merr) is a summer legume crop mainly cultivated for its seeds, with high oil and protein contents. Soybean area in Egypt has been dramatically decreased as a result of severe competition from strategic summer crops. Many studies from 1962 until now reported that maize and soybean were successfully intercropped in Egypt, like many countries in the world (Sayed Galal and Abdel Rassol, 1962; Metwally, 1973; Shafik, 1984; Abd El-Lateef, 1988; Metwally et al., 1988; Metwally, 1999; Shafik, 2000 and Metwally et al., 2003).

Nitrogen $(\mathrm{N})$ is the most important element for plant growth and development. It is an integral component of many compounds essential for plant growth processes including chlorophyll and many enzymes. The optimal 
amounts of these elements in the soils cannot be utilized efficiency if nitrogen is deficient in plants. Therefore, nitrogen deficiency or excess can result in reduced maize yields. Maize nitrogen requirement can be as high as 150 to $200 \mathrm{~kg} \mathrm{~N}$ per hectare (Mkhabela et al., 2001).

Many investigators reported that applied nitrogen significantly increased seed and grain yields of both uninoculated and inoculated soybeans and maize. Zada and Ahmed (1992) found that grain yield of both crops increased with increasing $\mathrm{N}$ rate both in pure stands and when intercropped. Sharma et al. (1994) found that maize grain yield was highest with $120 \mathrm{~kg} \mathrm{~N} / \mathrm{ha}$, while soybean seed yield decreased with increasing $\mathrm{N}$. Similar results were obtained by Misra et al. (2000), Pawar et al. (2005), Ramesh et al. (2005) and Saini et al. (2005).

Modern levels of crop production would be impossible without use of mineral fertilizers on large scale. However, in view of the problems of soil pollution, fertilizers costs and availability, there has been increasing emphasis in recent years on the importance of organic and bio-fertilization which bring about more efficient extraction of soil nutrients (Mkhabela et al., 2001). One of the reasons for intercropping legumes and non- legumes is that legumes may fix atmospheric $\mathrm{N}$ which would be available and transfer to the associated nonlegumes (Fujita et al., 1992).

Cereal/legume intercropping increases dry matter production and grain yield more than their monocultures. When fertilizer $\mathrm{N}$ is limited, biological nitrogen fixation (BNF) is the major source of $\mathrm{N}$ in legume-cereal mixed cropping systems (Fujita et al., 1992).

The objectives of the study were to investigate the integration of mineral nitrogen fertilization and diazotroph inoculation on yield of solid and intercropped maize with soybean.

\section{MATERIALS AND METHODS}

Two field trials were conducted at the Agricultural Experiments and Research Station, Faculty of Agriculture, Cairo University, Giza, at 2004 and 2005 summer seasons. Maize variety (Single hybrid 122) and soybean variety (Giza 111) were used in this study. Seeds were obtained from the Agricultural Research Center, Giza.

The solid systems of maize planting were recommended culture (solid 1) and dense culture (solid 2). These systems were conducted by thinning the maize hills, which spaced $25 \mathrm{~cm}$, before first irrigation to one (24000 plants/fad) and two (48000 plants/fad) plants for solid1 and solid2, respectively. The intercropping system was two ridges of maize alternating with two ridges of soybean (2:2 systems). The nitrogen applications (60, 90 and $120 \mathrm{~kg} \mathrm{~N} /$ faddan) were divided to three equal doses at planting, 21 and 40 days from sowing date. Nitrogen levels were applied according to plant population per faddan. Maize plants were grown on intercropping ridges similar to those of solid 2. Diazotroph inoculation of maize was performed using free microbial formulation biogramina (an inoculum of five associated diazotrophs), obtained from the Culture Collection of ESRU, Faculty of Agriculture, and Cairo University. Seeds were thoroughly washed in water 
prior to treatment to get rid of any traces of pesticides possibly added for seed pest control during storage. Maize was planted at 19 and 25 May in 2004 and 2005 seasons, respectively. Soybean seeds were inoculated with okadin (single culture of Bradyrhizobium japonicum) prior to seeding. Seeds were coated by peat mixed with Arabic gum ( $10 \mathrm{~g} / 3 \mathrm{ml} / 100 \mathrm{~g}$ seeds), mixed uniformly and directly drilled in two rows / ridge. Seedlings were thinned to two plants / hill distanced $10 \mathrm{~cm}$. one week later when the soil still contained adequate moisture.

The layout of the experiment was a split- split plot design $n$ Randomized Complete Blocks with three replications. Cropping systems were randomly assigned to main plots, nitrogen levels to the sub plots and inoculation to the sub-sub plots. The plot size (six ridges) was $6 \mathrm{~m}$ long $X 4.2$ $\mathrm{m}$ width. The homogeneity test of error variance of the two seasons indicated that errors were homogenous and combined analysis over seasons was performed. Data were analyzed according to Snedecor and Cochran (1967). The least significant differences (LSD) at the 0.05 probability level were applied to compare the means of treatments.

Recommended cultural practices were followed and the preceding crop in both seasons was faba bean.

Sample of six maize guarded plants was taken from each plot after 90 days from sowing and leaf area (LA) was measured according to Francis et al. (1969). At harvest, sample of 10 guarded plants from each plot was taken randomly to measure biological yield and grain yield/plant. Grain yield/plot was weight and converted to ardab/faddan. The yield of grains was adjusted to $15.5 \%$ moisture

Soil samples were collected just before planting for mechanical and chemical analyses (Table 1).

Table 1: Mechanical and chemical analyses of the experimental soil (average 2004 and 2005 seasons).

\begin{tabular}{lcc}
\hline Soil properties & Average \\
\hline Coarse sand & Soil particles $(\%)$ & 6.0 \\
Fine sand & & 37.4 \\
Silt & & 22.5 \\
Clay & 34.5 \\
Textural class & Chemical properties & \\
Available N $(\mathrm{ppm})$ & & 1750 \\
Available P(ppm) & & 2600 \\
Available K $(\mathrm{ppm})$ & 3500 \\
pH & 7.29 \\
E.C. $(\mathrm{mmhose} / \mathrm{cm})$ & 0.88 \\
Organic matter $(\%)$ & 1.27 \\
\hline
\end{tabular}




\section{RESULTS AND DISCUSSION}

\section{Effect of cropping systems, nitrogen fertilizer levels and diazotroph inoculation on maize characters:}

Effect of cropping systems, nitrogen fertilizer levels and inoculation on yield and yield components of maize are presented in Table 2. Data showed significant effects of cropping system on different maize characters.

Leaf area index (LAl) was significantly higher under intercropping and solid2 than solid1 planting. These because each hill comprised 2 plants in intercropping and solid2 and one plant in solid1. These results are in harmony with those reported by (Metwally et al., 2003).

Table 2:Effect of cropping systems, nitrogen fertilizer levels and inoculation on yield and yield components of maize (combined data of 2004 and 2005 seasons).

\begin{tabular}{|c|c|c|c|c|}
\hline Treatments & LAI & $\begin{array}{c}\text { Biological } \\
\text { yield/plan } \\
(\mathrm{g})\end{array}$ & $\begin{array}{l}\text { Grain yield / } \\
\text { plant } \\
\text { (g) }\end{array}$ & $\begin{array}{l}\text { Grain yield / } \\
\text { faddan (ardab) }\end{array}$ \\
\hline \multicolumn{5}{|l|}{ Cropping systems } \\
\hline Intercropping & 8.9 & 423.6 & 134.2 & 19.81 \\
\hline Solid 1 & 4.8 & 424.2 & 142.5 & 23.58 \\
\hline Solid 2 & 8.6 & 280.4 & 87.2 & 23.14 \\
\hline \multicolumn{5}{|l|}{ N-fertilizer levels (kg/fad) } \\
\hline 0 & 6.0 & 270.9 & 80.8 & 12.61 \\
\hline 60 & 7.8 & 366.2 & 126.6 & 23.56 \\
\hline 90 & 8.0 & 410.2 & 134.3 & 25.05 \\
\hline 120 & 8.0 & 457.0 & 143.4 & 27.49 \\
\hline $\begin{array}{l}\mathrm{LSD}_{0.05} \\
\text { Inoculation }\end{array}$ & 1.1 & 6.1 & 11.8 & 0.67 \\
\hline Uninoculated & 7.1 & 348.8 & 113.1 & 21.27 \\
\hline Inoculated & 7.7 & 403.4 & 129.5 & 23.08 \\
\hline F-test & $*$ & * & * & * \\
\hline
\end{tabular}

Doupling the plant population density in solid2 reduced significantly biological yield/plant, the rates of reductions were 33.8 and $33.9 \%$ compared to intercropping and solid1, respectively. This condition may have resulted in reduction in light intensity on solid2 planting than that of intercropping system. Doupling the plant population density in solid2 reduced significantly the grain yield/plant compared to solid 1 and intercropping systems. This may be attributed to the high competition between plants in hills as reported by Metwally et al. (2003). However, the recommended solid 1 plant density seemed to be the reliable for grain production of maize plants compared to higher density (solid2).But, the yield per plant of intercropped maize was higher than identical solid planting (solid2) by $35 \%$. Similar results were found by others (Shafik, 1984; Metwally et al., 2003).

Grain yield/faddan was significantly higher under the recommended plant density, solid1 (23.58 ardab/fad.) than under solid2 (23.14 ardab/fad.) 
and intercropping (19.81 ardab/fad.) plantings. The higher average grain yield of solid1 is mainly attributed to more areas actually planted by maize $(100 \%)$ than intercropping culture (50\%). Reduction of maize grain yield from intercropping culture was accompanied by significant reduction in yield components. Similar results were found by others (Shafik, 2000; Metwally et al., 2003). On the other hand, although the yield of intercropped maize plants was higher than solid2 culture, results showed that intercropping system gave the lowest maize grain/faddan than of solid2. This is because high plant population density of solid2 have compensated for the relatively lower yield per plant.

Nitrogen application significantly affected all the studied characters, as shown in Table (2). Increasing nitrogen application rates till $120 \mathrm{~kg}$ $\mathrm{N} /$ faddan increased LAI, biological yield, grain yield/plant and grain yield/faddan. LAI increased significantly as $\mathrm{N}$ levels increased from 0 to $60 \mathrm{~kg}$ $\mathrm{N} /$ faddan but there were no significant increments with more $\mathrm{N}$ applications.

Increasing nitrogen application rates till $120 \mathrm{~kg} \mathrm{~N} / \mathrm{fad}$ increased biological yield /plant. These increasing may be due to the role of nitrogen in increasing the plant height and production of more metabolites that led to heavier grain weight and its contribution to higher yield/plant. The biological yield/plant under $60 \mathrm{~kg} \mathrm{~N} /$ faddan increased compared to control (without $\mathrm{N}$ fertilizer) by ca. $26 \%$. Nitrogen application rate of $120 \mathrm{~kg} \mathrm{~N} /$ faddan increased biological yield/plant compared to $90 \mathrm{~kg} \mathrm{~N} /$ faddan by $10.2 \%$. The lowest grain yield per plant $(80.8 \mathrm{~g})$ was under zero $\mathrm{N}$. The grain yield/plant under 60 $\mathrm{kg} \mathrm{N} / \mathrm{fad}$ increased compared to zero nitrogen application by $36.2 \%$. Nitrogen levels of 90 and $120 \mathrm{~kg} \mathrm{~N} /$ faddan increased grain yield/plant compared to $60 \mathrm{~kg} \mathrm{~N} /$ faddan by about 5.7 and $11.7 \%$, respectively. This is in agreement with results reported by Mkhabela et al. (2001) and Osmar et al. (2004). The highest grain yield /faddan (27.49 ardab) occurred under $120 \mathrm{~kg}$ $\mathrm{N} /$ faddan while the lowest (12.61 ardab) was under zero nitrogen application. In general, as nitrogen level increased, the grain yield/faddan also increased. The rates of increases were $46.5,49.7$ and $54.1 \%$ at 60,90 and $120 \mathrm{~kg}$ $\mathrm{N} /$ faddan, respectively compared to zero $\mathrm{N}$. The statistical analysis showed that the mean grain yields achieved with 60 and 90,90 and $120 \mathrm{~kg} \mathrm{~N} /$ faddan were not significantly different.

Data in Table (2) also revealed that diazotroph inoculation of maize increased significantly each of LAI, biological and grain yield/plant and grain yield/faddan compared with uninoculated plants. The positive effects of bacterial inoculation are mainly attributed to the production of phytohermones that improve root development beside $\mathrm{N}_{2}$-fixation. These developments within the root system are important because they increase absorptive area and volume of soil substrate available to the plant, with subsequent increase in the rate of water and mineral uptake (Santa et al., 2004). The increases of each of biological, grain yield/plant and grain yield/ faddan due to inoculation were $13.5,12.7$ and $7.8 \%$, respectively compared to uninoculated maize. Osmar et al. (2004) indicated that inoculation with diaztrophs enhanced nitrogenase activity in root regions of Egyption cereals. Such findings supported the view that these bacteria produce growth regulating compounds mainly indole acetic acid, gibberillin and cytokinine like substances which 
may improve plant productivity by hormonal stimulation besides $\mathrm{N}_{2}$ - fixation (Shahaby et al., 2000). It is well established that inoculation with diazotrophs induced the proliferation of lateral roots and root hairs which increase nutrient absorbing surfaces and many more root tips available for infection. This is in agreement with results reported by Osmar et al. (2004).

\section{Effect of the interaction between cropping systems, nitrogen fertilizer levels and inoculation on maize characters:}

Data in Table (3) revealed that, LAI, biological yield and grain yield /plant were significantly affected by the interaction between cropping systems, nitrogen levels and inoculation. However, grain yield/ fad was not affected by the interaction between the three factors. The highest values of LAl were obtained from intercropping with $90 \mathrm{~kg} \mathrm{~N} /$ faddan and inoculation, but the lowest ones were obtained from solid1 with zero nitrogen levels and absence of diazotrophs.

The highest values of biological yield per plant $(515.4 \mathrm{~g} /$ plant $)$, grain yield per plant (172.4 g/plant) and grain yield/faddan (31.27 ardab/fad.) were obtained from solid1 with $120 \mathrm{~kg} \mathrm{~N} / \mathrm{fad}$ and inoculation, but the lowest values of these characters were obtained from solid2 with zero nitrogen fertilizer and uninoculation.

Inoculation seeds and fertilization of maize with $90 \mathrm{~kg} \mathrm{~N} / \mathrm{faddan}$ gave higher values of biological yield/plant under recommended solid and intercropping patterns, with no significant differences as compared with 120 $\mathrm{kg} \mathrm{N} /$ faddan. The effect of inoculation under zero $\mathrm{N}$ level was higher than those of high doses of nitrogen levels application under recommended solid and interplanting cultures. Also there were gradual decreases of ratios of increments for maize grains per plant by increasing nitrogen levels under different cropping patterns. This was probably due to better effect of inoculation under zero nitrogen which have been worked by the addition of $\mathrm{N}$ fertilizer. Also there were gradual decreases of ratios of increments for maize inoculated grains per faddan by increasing nitrogen levels under different cropping patterns. These values reduced from $75.6 \%, 7.7 \%$ and $15.2 \%$ for 0,90 and $120 \mathrm{~kg} \mathrm{~N} /$ faddan under intercropping pattern, the respective values were $70.5 \%, 12.6 \%$ and $8.3 \%$ under recommended solid planting. This means that increasing doses of $\mathrm{N}$ application cause an inhibition bio-fertilizer. These data are in harmony with those obtained by Shahaby et al. (2000) and Osmar et al. (2004). Appling 60 and $90 \mathrm{~kg} \mathrm{~N} /$ faddan in presence of diazotroph inoculation resulted in same yields of 90 - and $120 \mathrm{~kg} \mathrm{~N} / \mathrm{faddan}$ in absence of inoculation. This means that the microbial formulation "Biogramina" of associative diazotrophs successfully replaced the effect of 30 $\mathrm{kg} \mathrm{N} / \mathrm{fad}$ for maize plants. This authenticates the applicability of the integrated fertilizer management "IFM" concept in modern agriculture. This certainly introduces extraordinary benefits to the agricultural society by reducing the usual heavy mineral $\mathrm{N}$ fertilizer besides satisfying a great part of plant $\mathrm{N}$ requirements via biotic agent applications. 
J. Agric. Sci. Mansoura Univ., 32 (6), June, 2007

Table 3: The interaction of inoculation, $\mathbf{N}$ fertilization and cropping systems on maize growth and yield (combined data of 2004 and 2005 seasons).

\begin{tabular}{|c|c|c|c|c|c|c|}
\hline $\begin{array}{l}\text { Cropping } \\
\text { systems }\end{array}$ & $\begin{array}{c}\mathrm{N} \\
\text { Levels } \\
(\mathrm{kg} / \mathrm{fad})\end{array}$ & Inoculation & LAI & $\begin{array}{l}\text { Biological yield } \\
\text { /plant } \\
\text { (g) }\end{array}$ & $\begin{array}{l}\text { Grain } \\
\text { yield } \\
\text { /plant }(\mathrm{g})\end{array}$ & $\begin{array}{l}\text { Grain } \\
\text { yield /fad } \\
\text { (ardab) }\end{array}$ \\
\hline \multirow{8}{*}{ Inter } & \multirow{2}{*}{0} & Uninoculated & 6.4 & 266.7 & 70.5 & 9.63 \\
\hline & & Inoculated & 7.5 & 382.4 & 124.6 & 16.923 \\
\hline & \multirow{2}{*}{60} & Uninoculated & 8.3 & 360.3 & 137.8 & 20.61 \\
\hline & & Inoculated & 9.4 & 448.0 & 144.1 & 21.86 \\
\hline & \multirow{2}{*}{90} & Uninoculated & 10.0 & 424.4 & 140.4 & 21.23 \\
\hline & & Inoculated & 10.8 & 500.0 & 151.7 & 22.96 \\
\hline & \multirow{2}{*}{120} & Uninoculated & 8.7 & 495.4 & 147.8 & 21.04 \\
\hline & & Inoculated & 9.4 & 511.7 & 156.6 & 24.21 \\
\hline \multirow{8}{*}{ Solid 1} & \multirow{2}{*}{0} & Uninoculated & 3.5 & 269.3 & 76.1 & 11.70 \\
\hline & & Inoculated & 4.6 & 355.3 & 126.8 & 19.95 \\
\hline & \multirow{2}{*}{60} & Uninoculated & 4.2 & 356.8 & 137.6 & 22.13 \\
\hline & & Inoculated & 5.2 & 454.4 & 149.2 & 24.06 \\
\hline & \multirow{2}{*}{90} & Uninoculated & 5.0 & 425.8 & 146.0 & 23.81 \\
\hline & & Inoculated & 6.0 & 515.7 & 166.4 & 26.83 \\
\hline & \multirow{2}{*}{120} & Uninoculated & 4.7 & 500.7 & 165.2 & 28.89 \\
\hline & & Inoculated & 5.2 & 515.4 & 172.4 & 31.27 \\
\hline \multirow{9}{*}{ Solid 2} & \multirow{2}{*}{0} & Uninoculated & 6.4 & 165.6 & 39.8 & 8.05 \\
\hline & & Inoculated & 7.4 & 186.4 & 47.0 & 9.38 \\
\hline & \multirow{2}{*}{60} & Uninoculated & 8.0 & 283.3 & 92.7 & 27.93 \\
\hline & & Inoculated & 8.7 & 294.1 & 98.3 & 24.79 \\
\hline & \multirow{2}{*}{90} & Uninoculated & 8.9 & 293.0 & 95.5 & 29.28 \\
\hline & & Inoculated & 6.8 & 302.2 & 105.8 & 26.18 \\
\hline & \multirow{2}{*}{120} & Uninoculated & 8.0 & 344.1 & 107.8 & 30.94 \\
\hline & & Inoculated & 9.0 & 374.8 & 110.7 & 28.56 \\
\hline & \multicolumn{2}{|c|}{ LSD $_{0.05}$} & 1.8 & 10.3 & 3.5 & ns \\
\hline
\end{tabular}

ns, not significant

\section{REFERENCES}

Abd El-Lateef, E.M. (1988).Effect of some cultural practices on the intercropping of maize and soybean production. Ph.D. Thesis, Fac. Agric., Cairo Univ., Egypt.

Francis, C.A.; J.N. Rutger and A.F.E. Palmer (1969). A rapid method for plant leaf area estimation in maize (Zea mays L.). Crop Sci., 9: 537-539.

Fujita, K.; K.G. Ofosu-Budu and S. OGATA (1992).Biological nitrogen fixation in mixed legume.cereal cropping systems. Plant and Soil, 141: 155-175. 
Metwally, A.A (1973). The study of some companionship between maize and other crops. M.Sc. Thesis., Fac. Agric., Cairo Univ., Giza, Egypt.

Metwally, A.A. (1999). Intensive cropping system in the battle against food crises. Proc. 1st Conf. Recent technologies in Agric., Cairo Univ. 2729, Nov., 2: 333-341.

Metwally, A.A.; M.M.F. Abdalla; S.A. Shaban; A.A. El-Haffeez and E.O. Ewies (1988). Effect of nitrogen and phosphorus fertilization for cornsoybean intercrops. Assiut Agric. Sci. J., 19: 328-337.

Metwally, A. A.; El-M. A. El-Metwally; M. M. Shafik and S.A. Safina (2003).Tolerance of some maize varieties to intercropping. Proc.10th Conf. Agron., Suez Canal Univ., Fac., Environ., Agric., Sci., ElArshis, 7-10, Oct., Egypt. 279-293.

Misra, O. R.; A. M. Rajput; P. K. Wani and H. S. Thakur (2000). Study on planting patterns, nutrient management and economics in sorghumsoybean intercropping. Crop Research, 19 (1): 138-141.

Mkhabela, M. S. and J. Pali-Shikhulu (2001). Response of maize (Zea mays L.) cultivars to different levels of nitrogen application in Swazilanda. Seventh Estern and Southern Africa regional maize conference.11th15th February, 377-381.

Osmar R. Dalla Santa; Calors R. Soccol; Pedro Ronzelli Junior; Ramona Fernandez Hernadez; Georgina L. Michelena Alvarez; Herta S. Dalla Santa and Ashok Pandey (2004). Effects of inoculation of Azosprillium sp. in maize seeds under field conditions. Food, Agric.\&Environment, 2 (1):238-242.

Pawar, P. P.; H. E. Patil; P. M. Chaudhari and R. H. Hankare (2005). Effect of maize based cropping systems and fertility levels on productivity of rainfed maize. Journal of Maharashtra Agricultural Universities, Pune, India, 30 (3): 343-344.

Ramesh, P.; P. K. Ghosh; K. S. Reddy; Ajay; S. Ramana and R. S. Choudhary (2005). Assessment of biomass, productivity and sustainability of soybean based cropping systems at three levels of nitrogen in deep vertisols of semi-arid tropical India. J. of Sustainable Agric., 26 (2): 43-59.

Saini, V. K.; S. C. Bhandari; S. K. Sharma and J. C. Tarafdar (2005). Assessment of microbial biomass under integrated nutrient management in soybean-winter maize cropping sequence. Journal of the Indian Society of Soil Science, 53 (3): 346-351.

Santa, O. R. D.; C. R. Soccol; P. R. Junior; R. F. Hernández; G. L. M. Alvarez ; H. S. D. Santa and A. Pandey (2004). Effects of inoculation of Azospirillum sp. in maize seeds under field conditions. Food, Agriculture \& Environment, 2 (1): 238-242.

Sayed Galal, Jr. and S.F. Abdel-Rasool (1962). Possibilities of intercropping corn and soybean in Egypt. Official Report Tech., Comm. For Oil Crops, Ministry of Agric., Egypt.

Snedecor, G. W. and W. G. Cochran (1967). Statistical Methods 6 th ed., P. 381-418. lowa State Univ. Press. 
Shafik, M.M. (1984). The variability in intercropping tolerance among corn and soybean cultivars under different intercropping patterns. M. Sc. Thesis. Fac. Agric., Cairo Univ., Giza, Egypt.

Shafik, M.M. (2000). Genotypic differences in intercropping tolerance among maize and soybean genotypes. Egypt, J. Plant Breed., 4: 107-119.

Shahaby, A. F.; M. Fayez; M. N. Omar and Heba S. Shehata (2000). Intergration of diazotrophs inoculation with organic and inorganic fertilization to improve wheat and maize productivity in sandy soils. Egypt, J. Agric. Res., 78 (2): 499- 518.

Sharma, R. S.; K. K. Agrawal and K. K. Jain (1994). Influence of spatial arrangement and nitrogen levels on light utilization and productivity in maize-soybean intercropping system. J. of Oilseeds Res., 11 (2): 217-221.

Zada, K.and S. Ahmad (1992). Biologic and intercrop studies on yield and nitrogen fixation of soybean and maize. Sarhad J. of Agric., 8 (6): 613-622.

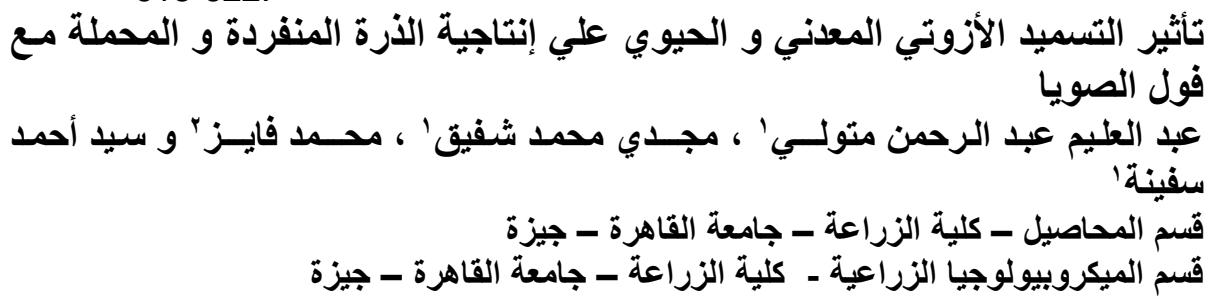

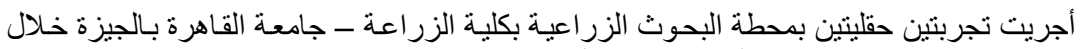

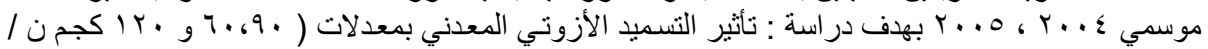

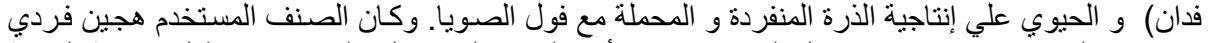

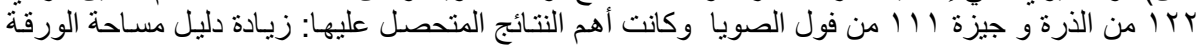

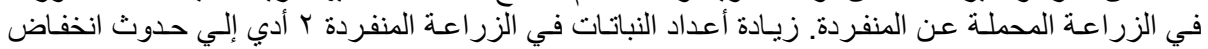

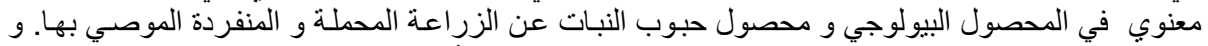

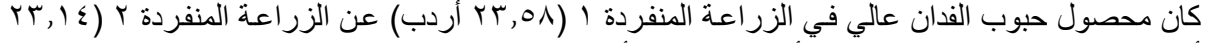

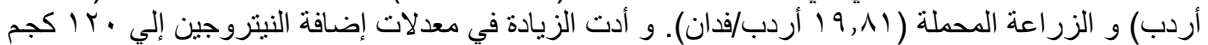

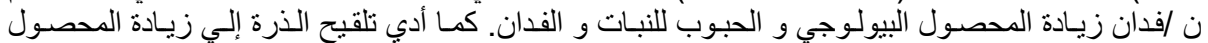

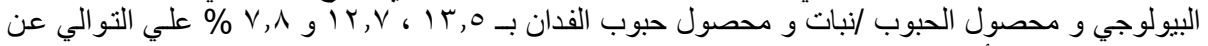

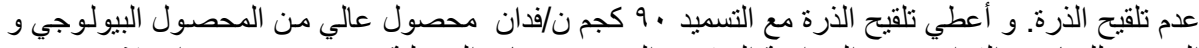

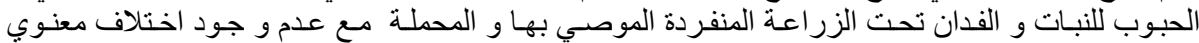

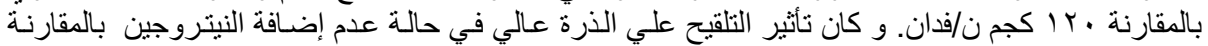

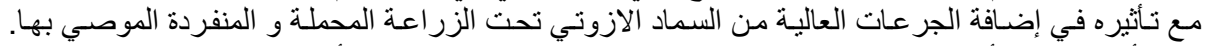

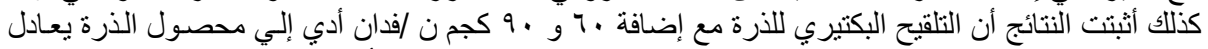

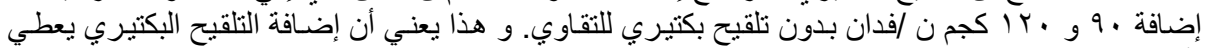

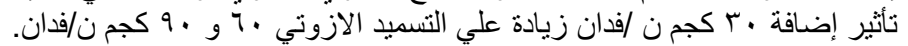

